\title{
Isolasi Dan Karakterisasi Senyawa $\alpha$-Amirin Dari Kulit Batang Binjai (Mangifera Caesia)
}

\author{
Kholifatu Rosyidah, ${ }^{*}$ Hj. Nor Latifah, Maria Dewi Astuti \\ Program Studi Kimia Fakultas MIPA Universitas Lambung Mangkurat \\ Jl. Jend. A. Yani Km 35,8 Banjarbaru 70714 Kalimantan Selatan \\ e-mail : kholifatu@yahoo.co.id
}

\begin{abstract}
Abstrak
Telah dilakukan isolasi dan karakterisasi senyawa $\alpha$-amirin dari kulit batang binjai (Mangifera caesia). Hasil analisis spektra IR menunjukkan adanya gugus $\mathrm{OH}, \mathrm{C}-\mathrm{H}, \mathrm{C}=\mathrm{C}$, dan gem dimetil. Spektra ${ }^{1} \mathrm{H}-\mathrm{NMR}$ dan ${ }^{13} \mathrm{C}-\mathrm{NMR}$ menunjukkan adanya 30 karbon, delapan diantaranya merupakan unit metil, dan satu ikatan rangkap. Struktur senyawa dikarakterisasi berdasarkan data spektroskopi IR dan NMR serta dibandingkan dengan data spektroskopi dari literatur. Berdasarkan data tersebut, senyawa hasil isolasi adalah $\alpha$-amirin.
\end{abstract}

Kata kunci: Mangifera caesia, triterpenoid, $\alpha$-amirin.

\begin{abstract}
The isolation and characterization of $\alpha$-Binjai amirin of bark (Mangifera caesia) had been done. The results of the analysis of IR spectra indicate the presence of an $\mathrm{OH}$ group, $\mathrm{CH}, \mathrm{C}=\mathrm{C}$, and the gem dimethyl. 1H-NMR spectra and 13C-NMR showed 30 carbon, eight of whom are methyl units, and one double bond. Structure of the compounds were characterized by IR and NMR spectroscopy data and compared with spectroscopic data from the literature. Based on these data, the compound is $\alpha$ amirin isolation.
\end{abstract}

Key words: Mangifera caesia, triterpenoids, $\alpha$-amirin.

\section{PENDAHULUAN}

Binjai merupakan tumbuhan khas Kalimantan Selatan dan tergolong dalam genus Mangifera. Nama lain dari buah binjai adalah kemang, binglu atau beluno. Binjai adalah pohon sejenis mangga dengan bau harum yang menusuk dan rasa yang asam manis. Tanaman binjai berbentuk pohon, tinggi tanaman mencapai 30-40 $\mathrm{m}$ dan diameter antara $50-120 \mathrm{~cm}$. Buah binjai berbentuk lonjong, dengan ukuran panjang $12-20$ dan lebar 6-12 $\mathrm{cm}$. Kulit buah tipis berwarna kekuningan hingga coklat. Daging buah putih susu, berserat, berbau dan rasanya asam manis. Biji berbentuk bulat lonjong dengan kulit tipis (Wardiyono, 2008).

Binjai menyebar secara alami di Sumatera, Kalimantan dan Semenanjung Malaya, sebagian pakar meyakini Kalimantan adalah lokasi asal -usulnya. Dari wilayah-wilayah ini, binjai dibawa dan dibudidayakan orang di Bali, Filipina dan Thailand, serta sebagian di Jawa (Kostermans \& Bompard, 1993). Binjai termasuk tumbuhan dari genus Mangifera (manggamanggaan) dan merupakan bagian dari famili Anacardiaceae. Famili Anacardiaceae terdiri dari 82 genus dan banyak mengandung senyawa triterpen. Beberapa senyawa triterpen dilaporkan aktif antiinflamasi, anti kanker, anti leukimia, anti malaria dan anti HIV (Salminen et al., 2008).

Senyawa $\alpha$-amirin merupakan salah satu senyawa golongan triterpenoid. Senyawa $\alpha$ amirin mempunyai aktivitas sebagai analgesik, anti inflamasi (anti peradangan) dan anti kanker (Dzubak, et al., 2005). Selain itu, penelitian Prasetya \& Zetra (2007) menyebutkan bahwa hasil uji toksisitas dengan Brine-Shrimp Lethality Test (BSLT) menunjukkan bahwa $\alpha$-amirin bersifat aktif dengan nilai LC $_{50}$ sebesar 49,86 
ppm sedangkan uji insektisida menggunakan larva Ae. aegypti instar 3 juga bersifat aktif dengan nilai $\mathrm{LC}_{50} 72,54 \mathrm{ppm}$.

\section{METODE PENELITIAN}

\section{Alat dan bahan}

Penentuan struktur senyawa hasil isolasi dilakukan berdasarkan data spektra UV (spektrofotometer UV Varian Conc.100), spektra IR (spektrofotometer FTIR Perkin Elmer Spectrum One) dan spektra NMR ditentukan dengan (Bruker AM 500 pada $500 \mathrm{MHz}\left({ }^{1} \mathrm{H}\right)$ dan $\left.125 \mathrm{MHz}\left({ }^{13} \mathrm{C}\right)\right)$. Pelarut organik berkualitas teknis seperti metanol, etanol, $n$-heksana, metilen klorida, etil asetat, aseton, dan kloroform berkualitas p.a Merck, $\mathrm{H}_{2} \mathrm{SO}_{4} 97 \% \mathrm{p}=1,84 \mathrm{~kg} / \mathrm{l}$, $\mathrm{CeSO}_{4} 1,5 \%$ dalam $\mathrm{H}_{2} \mathrm{SO}_{4} 2 \mathrm{~N}$, silika gel Merck 60 GF254, silika gel 60 (60-70 mesh), plat KLT menggunakan plat aluminum berlapis silika gel Merck Kieselgel $60 \mathrm{~F}_{254}$ setebal 0,25 mm, dan aluminium foil.

\section{Sampel penelitian}

Fraksi saponin $(34,44$ gram) dari ekstrak metanol kulit batang binjai (Mangifera caesia).

\section{Fraksinasi dan Isolasi}

Fraksi saponin dipisahkan dengan cara Kromatografi Vakum Cair (KVC). Elusi diawali dengan pelarut non polar yaitu n-heksana kemudian dilanjutkan dengan polaritas meningkat mulai dari campuran $n$-heksana:etil asetat, kemudian etil asetat sehingga diperoleh 35 fraksi. Fraksi-fraksi hasil KVC kemudian dianalisis dengan KLT menggunakan eluen $n$-heksana:etil asetat (6:4) dan diperoleh sepuluh fraksi gabungan (A-J). Fraksi C tampak sebagai noda tunggal, sehingga dilakukan uji kemurnian dengan tiga sistem eluen yaitu eluen $n$ heksana:etil asetat (7:3), metanol:kloroform (1:9), dan metilen klorida:etil asetat (9:1). Masingmasing sistem eluen menunjukkan satu noda sehingga fraksi $\mathrm{C}$ dikatakan murni. Selanjutnya fraksi $\mathrm{C}$ disebut sebagai senyawa hasil isolasi dan diperoleh sebanyak 5,29 mg. Senyawa hasil isolasi dilakukan uji kualitatif dengan pereaksi Lieberman Burchard dan dianalisis strukturnya dengan metode spektroskopi IR, ${ }^{1} \mathrm{H}-\mathrm{NMR}$ dan ${ }^{13} \mathrm{C}$-NMR.

\section{HASIL DAN PEMBAHASAN}

Senyawa hasil isolasi menjadi berwarna merah dengan pereaksi Lieberman Burchard, hal ini menunjukkan bahwa senyawa hasil isolasi merupakan senyawa golongan triterpenoid. Berdasarkan spektra IR senyawa hasil isolasi menunjukkan adanya pita (kuat, lebar) yang khas pada bilangan gelombang $3304 \mathrm{~cm}^{-1}$ menunjukkan adanya regang $\mathrm{O}-\mathrm{H}$ yang diperkuat adanya pita serapan ikatan $\mathrm{C}-\mathrm{O}$ pada bilangan gelombang $1056 \mathrm{~cm}^{-1}$. Kedua serapan tersebut mengidentifikasikan adanya gugus hidroksil (OH). Munculnya dua pita di daerah $2920 \mathrm{~cm}^{-1}$ dan $2850 \mathrm{~cm}^{-1}$ memperlihatkan adanya gugus C$\mathrm{H}$ alifatik. Adanya vibrasi tekuk $\mathrm{C}-\mathrm{H}$ yang mengindikasikan adanya gugus gem dimetil sebagai ciri khas senyawa triterpenoid pada bilangan gelombang $1462 \mathrm{~cm}^{-1}$ dan $1377 \mathrm{~cm}^{-1}$. Adanya karbon ikatan rangkap $(\mathrm{C}=\mathrm{C})$ ditunjukkan dengan adanya vibrasi ulur pada bilangan gelombang $1651 \mathrm{~cm}^{-1}$. Berdasarkan data IR maka senyawa hasil isolasi diduga sebagai senyawa terpenoid yang memiliki gugus hidroksil $(\mathrm{OH})$, karbon ikatan rangkap $(\mathrm{C}=\mathrm{C})$, dan gem dimetil.

Spektra ${ }^{1} \mathrm{H}-\mathrm{NMR}$ memberikan informasi posisi $\mathrm{H}$ pada struktur senyawa. Sinyal proton ikatan rangkap muncul pada geseran kimia 5,34 ppm yang sesuai dengan spektra IR. Adanya proton hidroksil $(\mathrm{OH})$ yang ditujukkan pada geseran kimia 3,67 ppm. Gugus gem dimetil pada spektra IR diperkuat dengan adanya sinyal singlet pada 0,94 dan $0,79 \mathrm{ppm}$. Terdapat proton metil singlet lainnya pada geseran kimia $0,80 \mathrm{ppm}$; $0,87 \mathrm{ppm}\left(2 \mathrm{xCH}_{3}\right) ; 0,92 \mathrm{ppm}$ dan $1,01 \mathrm{ppm}$ $\left(2 \mathrm{xCH}_{3}\right)$.

Spektroskopi ${ }^{13} \mathrm{C}-\mathrm{NMR}$ memberikan informasi mengenai struktur karbon dalam sebuah molekul yang dilihat dari geseran kimianya. Spektra ${ }^{13} \mathrm{C}$-NMR menunjukkan adanya gugus gem dimetil dari golongan triterpenoid pada geseran kimia pada 29,89 ppm dengan intensitas lebih tinggi. Hal ini mengindikasikan bahwa atom karbon mengikat gugus gem dimetil. Data ini khas untuk triterpenoid pentasiklik dengan satu 
gugus gem dimetil yang tersubsitusi pada $\mathrm{C} 4$ (Lima, 2004). Ciri adanya senyawa triterpenoid pentasiklik lainnya adalah memiliki 30 atom karbon dengan komposisi 8 sinyal karbon metil $\left(\mathrm{CH}_{3}\right)$ pada geseran kimia 29,$32 ; 12,17 ; 12,04$; 18,$96 ; 23,24 ; 29,14 ; 19,21$; dan 21,27 ppm. Adanya 9 sinyal karbon metilen $\left(\mathrm{CH}_{2}\right)$ pada geseran kimia 36,$68 ; 37,43 ; 19,58 ; 32,09 ; 22,88$; 26,23; 31,62; 42,50; dan 29,35 ppm. Adanya 7 sinyal karbon metin $(\mathrm{CH})$ pada geseran kimia 72,$03 ; 39,96 ; 31,83 ; 32,11 ; 46,01 ; 56,23$; dan $56,94 \mathrm{ppm}$. Sinyal pada geseran kimia 72,03 ppm merupakan sinyal khas untuk atom karbon yang mengikat gugus hidroksi $(\mathrm{OH})$ pada posisi C 3 untuk senyawa triterpenoid pentasiklik. Selanjutnya 6 sinyal karbon pada geseran kimia 29,$89 ; 46,01 ; 34,01 ; 121,94 ; 46,50$ dan 34,11 ppm. Data spektra IR dan spektra ${ }^{1} \mathrm{H}-\mathrm{NMR}$ yang menunjukkan adanya karbon ikatan rangkap $(\mathrm{C}=\mathrm{C})$ diperkuat dengan data spektra ${ }^{13} \mathrm{C}-\mathrm{NMR}$, yaitu dengan adanya dua sinyal karbon pada geseran kimia 140,91 dan 121,94 ppm yang khas untuk senyawa triterpenoid pentasiklik yang mempunyai ikatan rangkap karbon pada posisi C12 dan C13 (Pant, 1979).

Data hasil analisis spektra IR, ${ }^{1} \mathrm{H}-\mathrm{NMR}$ dan ${ }^{13} \mathrm{C}$-NMR menunjukkan bahwa senyawa hasil isolasi termasuk dalam golongan triterpenoid pentasiklik yang memiliki satu gugus hidroksil pada C 3, satu ikatan rangkap pada $\mathrm{C} 12$ dan $\mathrm{C} 13$ serta delapan gugus metil (dua diantaranya gugus gem dimetil pada C 4). Struktur senyawa hasil isolasi diduga merupakan senyawa triterpenoid pentasiklik dengan kerangka dasar ursan yaitu $\alpha$ amirin, seperti yang ditemukan pada kulit batang tumbuhan Bellschmiedia roxburghiana (Prasetya \& Zetra, 2007). Perbandingan data spektra ${ }^{1} \mathrm{H}$ dan ${ }^{13} \mathrm{C}-\mathrm{NMR}$ yang menunjukkan adanya kemiripan antara senyawa hasil isolasi dan $\alpha$-amirin ditampilkan pada Tabel 1.

Tabel 1. Perbandingan data ${ }^{1} \mathrm{H}$ dan ${ }^{13} \mathrm{C}$-NMR antara senyawa hasil isolasi dan $\alpha$-amirin

\begin{tabular}{|c|c|c|c|c|}
\hline Karbon & $\delta^{13} \mathrm{C}(\alpha$-amirin $)$ & $\delta^{13} \mathrm{C}(\alpha$-amirin $)$ & $\delta^{13} \mathrm{C}$ (senyawa) & $\delta^{13} \mathrm{C}$ (senyawa) \\
\hline 1 & 38,33 & & 36,68 & \\
\hline 2 & 32,10 & & 32,09 & \\
\hline 3 & 72,0 & $3,22(1 \mathrm{H}, \mathrm{dd})$ & 72,03 & $3,67(1 \mathrm{H}, \mathrm{s})$ \\
\hline 4 & 38,33 & & 29,89 & \\
\hline 5 & 56,24 & & 56,23 & \\
\hline 6 & 31,42 & & 31,62 & \\
\hline 7 & 28,43 & & 29,35 & \\
\hline 8 & 39,96 & & 39,96 & \\
\hline 9 & 46,03 & & 46,01 & \\
\hline 10 & 34,13 & & 34,01 & \\
\hline 11 & 26,26 & & 26,23 & \\
\hline 12 & 140,94 & $5,34(1 \mathrm{H}, \mathrm{t})$ & 140,91 & $5,34(1 \mathrm{H}, \mathrm{s})$ \\
\hline 13 & 121,90 & & 121,94 & \\
\hline 14 & 42,49 & & 42,50 & \\
\hline 15 & 23,26 & & 22,88 & \\
\hline 16 & 18,96 & & 18,96 & \\
\hline 17 & 34,13 & & 34,11 & \\
\hline 18 & 59,71 & & 56,94 & \\
\hline 19 & 39,6 & & 32,11 & \\
\hline 20 & 39,6 & & 31,83 & \\
\hline 21 & 42,49 & & 42,46 & \\
\hline 22 & 38,33 & & 37,43 & \\
\hline 23 & 28,43 & $0,99(3 \mathrm{H}, \mathrm{s})$ & 29,14 & $0,94(3 \mathrm{H}, \mathrm{s})$ \\
\hline 24 & 12,17 & $0,79(3 \mathrm{H}, \mathrm{s})$ & 12,17 & $0,79(3 \mathrm{H}, \mathrm{s})$ \\
\hline 25 & 12,04 & $0,94(3 \mathrm{H}, \mathrm{s})$ & 12,04 & $0,87(3 \mathrm{H}, \mathrm{s})$ \\
\hline 26 & 18,97 & $1,01(3 \mathrm{H}, \mathrm{s})$ & 19,21 & $1,01(3 \mathrm{H}, \mathrm{s})$ \\
\hline 27 & 23,26 & $1,06(3 \mathrm{H}, \mathrm{s})$ & 23,24 & $1,01(3 \mathrm{H}, \mathrm{s})$ \\
\hline 28 & 28,43 & $0,80(3 \mathrm{H}, \mathrm{s})$ & 29,32 & $0,80(3 \mathrm{H}, \mathrm{s})$ \\
\hline 29 & 18,97 & $0,79(3 \mathrm{H}, \mathrm{s})$ & 19,58 & $0,87(3 \mathrm{H}, \mathrm{s})$ \\
\hline 30 & 21,28 & $0,92(3 \mathrm{H}, \mathrm{s})$ & 21,27 & $0,92(3 \mathrm{H}, \mathrm{s})$ \\
\hline
\end{tabular}

Berdasarkan Tabel 1 terdapat beberapa kemiripan antara senyawa $\alpha$-amirin dan senyawa hasil isolasi. Satu proton yang merupakan gugus hidroksil pada C 3 muncul pada geseran kimia 3,22 ppm untuk $\alpha$-amirin yang tidak jauh beda dengan senyawa hasil isolasi yang muncul pada 
geseran kimia 3,67 ppm. Gugus gem dimetil senyawa hasil isolasi muncul pada geseran kimia 0,94 dan 0,79 ppm sedangkan $\alpha$-amirin pada geseran kimia 0,99 dan 0,79 ppm. Adanya ikatan rangkap yang khas untuk senyawa triterpenoid pentasiklik pada $\mathrm{C} 12$ dan $\mathrm{C} 13$ ditunjukkan pada geseran kimia 5,34 ppm yang juga terdapat pada $\alpha$-amirin. Adanya karbon rangkap yang khas dari senyawa triterpenoid pentasiklik ditunjukkan $\alpha$ amirin pada geseran kimia 140,94 dan 121,90 ppm sedangkan pada senyawa hasil isolasi muncul pada geseran kimia 140,91 dan 121,94 ppm. Berdasarkan analisis di atas maka senyawa hasil isolasi adalah $\alpha$-amirin seperti pada Gambar 1. Senyawa $\alpha$-amirin diketahui juga terkandung pada batang $M$. indica (Connolly, et al., 1970) yang masih dalam satu genus dengan $M$. caesia.

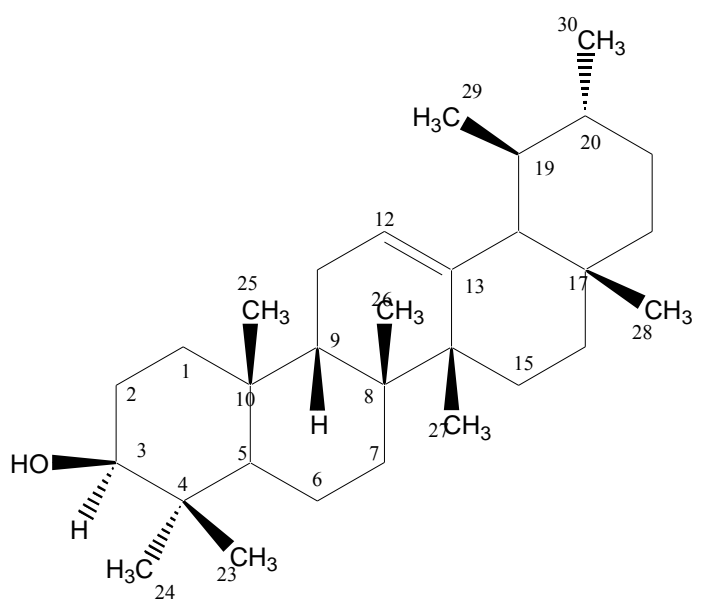

Gambar 1. Struktur senyawa $\alpha$-amirin

\section{KESIMPULAN}

Dari hasil penelitian yang telah dilakukan, diperoleh kesimpulan, yaitu senyawa hasil isolasi dari batang binjai berdasarkan uji kualitatif termasuk golongan triterpenoid. Hasil analisis spektra IR menunjukkan adanya gugus $\mathrm{OH}, \mathrm{C}-\mathrm{H}, \mathrm{C}=\mathrm{C}$, dan gem dimetil. Spektra ${ }^{1} \mathrm{H}-$ NMR dan ${ }^{13} \mathrm{C}$-NMR menunjukkan adanya 30 karbon, delapan diantaranya merupakan unit metil, dan satu ikatan rangkap. Struktur senyawa dikarakterisasi berdasarkan data spektroskopi IR, dan NMR serta dibandingkan dengan data spektroskopi dari literatur. Berdasarkan data tersebut, senyawa hasil isolasi adalah $\alpha$-amirin.

\section{UCAPAN TERIMA KASIH}

Peneliti mengucapkan terima kasih kepada laboratorium kimia LIPI yang telah membantu analisis spektroskopi IR, dan NMR.

\section{DAFTAR PUSTAKA}

1. Connolly, J.D., J. Polonsky, \& K.H. Overton. 1970. Advanc . Phytochem. 2: 385.

2. Dzubak, P., M. Hadjuch., D. Vydra., A. Hustova., M. Kvasnica., D. Biederman., L. Markota., M. Urban, \& J. Sarek. 2006. Pharmacological Activities of Natural Triterpenoids and Their Therapeutic Implications. Natural Product Reports. 23: 394-411.

3. Kostermans, A.J.G.H \& J.M. Bompard. 1993. The Mangoes. Their Botany, Nomenclature, Horticulture and Utilization . Academic Press Harcourt Brace \& Company, London.

4. Lima, M. 2004. Phitochemical of Trattinica buserfolia, T. rhifolia, and Decryodes. Journal Brazilia Chem. Soc. 15 (3): 385-389.

5. Pant, P. 1979. The Triterpenoids. Phytochemistry. 18: 1095-1108.

6. Prasetya, P \& Y. Zetra. 2007. Isolasi Senyawa -amirin dari Tumbuhan Bellischmiedia roxburghiana (Medang) dan Uji Bioaktivitasnya. Aktakindo. 3 (1): 27-32.

7. Salminen A, Lehtonen $M$, Suuronen $T$, Kaarniranta K, Huuskonen J., 2008,Terpenoids: natural inhibitors of NFkappaB signaling with anti-inflammatory and anticancer potential. Cell Mol Life Sci. 65(19):2979-99.

8. Wardiyono. 2008. Prohati-Keanekaragaman Hayati Tumbuhan Indonesia http://www.kehati.or.id/prohati/index.php, Diakses tanggal 11 Maret 2008 